\title{
Article \\ Effect of Compost Extract Addition to Different Types of Fertilizers on Quality at Harvest and Shelf Life of Spinach
}

\author{
Almudena Giménez ${ }^{1}\left(\mathbb{D}\right.$, Perla A. Gómez ${ }^{2, *(1)}$, María Ángeles Bustamante ${ }^{3}\left(\mathbb{D}\right.$, María Dolores Pérez-Murcia ${ }^{3}$,

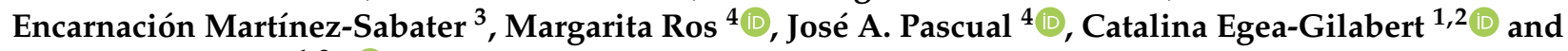 \\ Juan A. Fernández $1,2, * \mathbb{0}$
}

Citation: Giménez, A.; Gómez, P.A.; Bustamante, M.Á.; Pérez-Murcia, M.D.; Martínez-Sabater, E.; Ros, M.; Pascual, J.A.; Egea-Gilabert, C.; Fernández, J.A. Effect of Compost Extract Addition to Different Types of Fertilizers on Quality at Harvest and Shelf Life of Spinach. Agronomy 2021, 11, 632. https://doi.org/10.3390/ agronomy11040632

Academic Editors: Alberto San Bautista and Pedro Javier Zapata

Received: 25 February 2021

Accepted: 24 March 2021

Published: 26 March 2021

Publisher's Note: MDPI stays neutral with regard to jurisdictional claims in published maps and institutional affiliations.

Copyright: (c) 2021 by the authors. Licensee MDPI, Basel, Switzerland. This article is an open access article distributed under the terms and conditions of the Creative Commons Attribution (CC BY) license (https:/ / creativecommons.org/licenses/by/ $4.0 /)$.
1 Departamento de Ingeniería Agronómica, Universidad Politécnica de Cartagena, Paseo Alfonso XIII, 48, 30203 Cartagena, Spain; almudena.gimenez@upct.es (A.G.); catalina.egea@upct.es (C.E.-G.)

2 Instituto de Biotecnología Vegetal, Edificio I+D+i, Campus Muralla del Mar, 30202 Cartagena, Spain

3 Departamento de Agroquímica y Medioambiente, Universidad Miguel Hernández, UMH-EPSO, ctra. BenielKm 3.2, 03312 Orihuela, Spain; marian.bustamante@umh.es (M.Á.B.); perez.murcia@umh.es (M.D.P.-M.); e.martinezs@umh.es (E.M.-S.)

4 Conservación de Suelos y Agua y Manejo de Residuos Orgánicos, CEBAS-CSIC, Campus de Espinardo, 30100 Murcia, Spain; margaros@cebas.csic.es (M.R.); jpascual@cebas.csic.es (J.A.P.)

* Correspondence: perla.gomez@upct.es (P.A.G.); juan.fernandez@upct.es (J.A.F.)

Abstract: Spinach is rich in minerals, vitamins, phytochemicals and bioactive compounds with health-beneficial effects; however, this plant also tends to accumulate oxalates and nitrates in their leaves. Apart from genotype, nutrition is the pre-harvest factor that mostly affects quality attributes at harvest. Particularly, the application of compost extracts (CE) may induce resistance against soil-borne diseases and favour secondary metabolism, increasing antioxidant capacity. The objective of this study was to evaluate the effects of different types of fertilization with or without the addition of $\mathrm{CE}$, on harvest quality and shelf life of minimally processed spinach (Spinacia oleracea, var. Shrike RZ) stored during 12 days at $4{ }^{\circ} \mathrm{C}$. A compost extract (CE) was prepared by mixing a compost from agri-food wastes (vine pruning, leek waste and olive mill waste) with deionized water. CE foliar applications were done from days 28 and 56 after sowing. The treatments applied were: Control; Control + CE; NPK (inorganic NPK fertilizer 15-15-15); NPK + CE; DMPP (ENTEC Nitrofoska ${ }^{\circledR}$ plus the nitrification inhibitor 3,4-dimethylpyrazole phosphate (DMPP)) and DMPP + CE. After harvest, spinach leaves were minimally processed and packaged to generate a passive modified atmosphere. Nitrate content in the control treatment was reduced by the addition of CE, although in the rest of the treatments, $\mathrm{CE}$ addition did not produce any effect. For nitrite contents, the lowest value was obtained for the Control + CE. Moreover, the oxalate content was the lowest for the control treatment with a decreasing trend throughout the storage. The treatment Control $+\mathrm{CE}$ also showed the highest initial total phenolic contents, with very similar values at the end of shelf life to those observed at harvest for all the treatments. The highest differences in color as regards the initial values were detected for DMPP. Microbial loads increased for all the treatments without differences between them. The atmosphere reached at the end of the cold storage was the same for all the cases, with $\mathrm{CO}_{2}$ and $\mathrm{O}_{2}$ around $10 \mathrm{kPa}$ for each one of them. After 12 days at $4{ }^{\circ} \mathrm{C}$, all the treatments were above the limit of usability, with the spinach leaves acceptable for consumption. The results found in this study indicate that the addition of CE might be convenient for obtaining spinach rich in bioactive compounds and with low concentrations of antinutritional factors, without affecting the microbial load of the final product.

Keywords: fertilization; Spinacia oleracea L.; nitrate; oxalate; antioxidants; minimal processing

\section{Introduction}

Spinach is a green leafy vegetable considered a functional food because it is rich in mineral elements, vitamins, phytochemicals and bioactive compounds [1]. It has been demon- 
strated that spinach has a particularly high concentration of carotenoids and polyphenolic compounds, whose content might change at different growing and storage conditions [2]. The spinach leaves exhibit a high antioxidant capacity, especially due to the contents in phenolic acids and flavonoids, their concentration being in mid-mature leaves higher than in those immature or mature leaves [3]. However, spinach leaves might also accumulate a high concentration of oxalates [4] and nitrates [5], which can be considered as antinutritional compounds. In particular, oxalic acid can react with certain elements to form insoluble salts which may then lead to the formation of kidney stones [6], while nitrate can be converted into nitrite in the digestive tract [7], with poisoning effects [5].

Minimally processed vegetables attract consumer attention due to the increasing demand for both convenience and high-quality nutritious food products [8]. Among them, spinach is one of the most important in terms of production and consumption, with varied products existing in the market such as baby, teen and bunching spinach. In any case, detached spinach leaves quickly lose their freshness attributes (green colour, tissue hydration) and nutritional properties [9]. The main physical attribute to describe spinach freshness is turgor (low percentage of weight loss) [10], although the yellowing of leaves is also an important aspect for describing quality [11]. For keeping quality and extending spinach shelf life, cold storage at temperatures below $5{ }^{\circ} \mathrm{C}$ is advisable, with the standardized use of passive modified atmosphere packaging, with $\mathrm{N} 2 \mathrm{O}-$ enriched atmospheres seen as a promising alternative [12]. In addition, Medina et al. [13] demonstrated that short postharvest storage under low relative humidity $(75 \%)$ before processing $\left(36 \mathrm{~h}, 15^{\circ} \mathrm{C}\right)$ improves the quality and shelf life of minimally processed baby spinach reducing the microbiological population and maintaining an acceptable visual quality.

Apart from genotype, some pre-harvest factors, including environmental and agronomic factors, affect the harvest quality attributes, and postharvest physiology and shelf life of fresh horticultural commodities [14]. Among agronomic factors, plant nutrition has strong effects on leafy vegetable quality. Zikalala et al. [15] demonstrated that varying fertiliser application in baby spinach significantly influenced its phytochemical properties and nutritional quality. Particularly, adequate nitrogen $(\mathrm{N})$ fertilisation improved spinach production and quality, reducing environmental pollution and economic losses [16]. Nowadays, the use of novel fertilizers may fulfil the nitrogen requirements of the crop, decreasing the environmental impact of production and achieving a circular economy by closing nutrient loops [17]. It has been demonstrated that the negative effects of nitrate leaching and atmospheric $\mathrm{N}_{2} \mathrm{O}$ loads could be mitigated by the nitrification inhibitor 3,4-dimethylpyrazole phosphate (DMPP), which inhibits nitrification by reducing the abundance and metabolic activity of ammonia-oxidizing bacteria in alkaline soils [18]. Moreover, compost extracts (CE), a compost-derived product, are used as a source of nutrients to improve crop production, representing an inducer of systemic acquired resistance against soil-borne diseases. $\mathrm{CE}$ can contain biostimulant agents that increase the photosynthetic function of the plant, which can induce the activation of the plant's secondary metabolism, causing an increase in the content of total phenolics and flavonoids and boosting the antioxidant capacity in baby spinach [19]. Additionally, Giménez et al. [20] demonstrated that the CE application in lettuce did not have an effect on the microbial load of the final product at harvest and during shelf-life.

Therefore, a comprehensive assessment must be carried out to determine the potential of different fertilizing strategies for leafy vegetables to reach the goals of increasing product quality at harvest, enhancing the content of potentially health-promoting substances, and reducing the presence of anti-nutritional compounds, as well as improving postharvest shelf-life. Thus, the objective of this study was to evaluate the effects of different types of fertilization, with or without the addition of a compost extract, on harvest quality and shelf life of spinach during storage as a minimally processed product. 


\section{Materials and Methods}

\subsection{Plant Material and Experimental Design}

The farm experiment was conducted in Librilla, Murcia (Spain), at the SME Hermanos Lucas SL facilities $\left(37^{\circ} 55^{\prime} 08.9^{\prime \prime} \mathrm{N} 1^{\circ} 17^{\prime} 27.3^{\prime \prime} \mathrm{W}\right)$. The soil at the site was classified as clayey soil on the basis of USDA ( $44 \%$ clay, $35 \%$ sand, and $21 \%$ silt) and had an alkaline $\mathrm{pH}$, low salinity, low concentration of total nitrogen $\left(0.96 \mathrm{~g} \mathrm{~kg}^{-1}\right)$ and poor oxidizable organic carbon content $\left(5.74 \mathrm{~g} \mathrm{~kg}^{-1}\right)$. Soil characterization was conducted following the methods described by Vico et al. [17]. The commercial cultivar of spinach (var. Shrike RZ, with resistance to Peronospora farinosa f.sp. spinaciae) was sown on 15 November 2019, at a density of 150,000 plants ha $^{-1}$ (plant density according to the company protocol for this crop), and harvested on 3 February 2020, 80 days after seeding (das). The growing mean value of the daily average temperature was $10.7^{\circ} \mathrm{C}\left(\max .23 .8^{\circ} \mathrm{C}\right.$, $\left.\min -1.8^{\circ} \mathrm{C}\right)$, total rainfall was $160.6 \mathrm{~mm}$ and average relative humidity and radiation were $74.31 \%$ and $99.61 \mathrm{~W} / \mathrm{m}^{2}$, respectively.

Two types of treatments were considered: (a) fertilization treatments without compost extract (CE) (Inorganic NPK fertilizer 15-15-15 (compound NPK fertilizer-Fertiberia); ENTEC ${ }^{\circledR}$ Nitrofoska ${ }^{\circledR} 21$ plus the nitrification inhibitor 3,4-dimethylpyrazole phosphate (DMPP), Eurochem (21-8-11 (NPK) + 0.8\% DMPP); (b) fertilization treatments with CE (Inorganic NPK 15-15-15 plus compost extract (NPK + CE); DMPP treatment plus compost extract (DMPP $+\mathrm{CE})$. These fertilization treatments were applied as a single traditional application dose of $150 \mathrm{~kg}$ total $\mathrm{N} \mathrm{ha}^{-1}$ (expressed on a fresh weight basis), consisting of $6.12 \mathrm{Mg} \mathrm{ha}^{-1}$ of NPK and $4.36 \mathrm{Mg} \mathrm{ha}^{-1}$ of NPK. Additionally, a treatment without any fertilization was included as a control treatment, also without CE (Control) and with CE (Control + CE). The selection of the treatments was based on their use in the commercial production systems of the studied agricultural area. The fertilizers were incorporated immediately prior to sowing the crop on the soil surface and mixed $(0-10 \mathrm{~cm}$ depth) using a rotovator.

The compost extract (CE) was prepared by mixing compost (45.6\% vine pruning, $20.8 \%$ leek waste and $33.7 \%$ olive mill waste (sieved at $<0.7 \mathrm{~cm}$ ) with distillate water at a ratio of 1:100 $(w / v)$, without agitation and with forced aeration for $24 \mathrm{~h}$ at $25^{\circ} \mathrm{C}$ just before foliar application with a dose $1 \mathrm{Lm}^{-2}$. The compost extract (CE) was applied at 28 and 56 das for each treatment. The compost extract was characterized following the methods described by Bustamante et al. [21]. The main CE chemical characteristics are shown in Table 1. The experiment was arranged as a randomized complete block design with three replicates per treatment. Each replicate was carried out in $0.42 \mathrm{~m} \times 1.4 \mathrm{~m}$ plots randomly located.

Table 1. Physico-chemical and chemical characteristics of compost extract.

\begin{tabular}{cc}
\hline Parameter & Compost Extract \\
\hline $\mathrm{pH}$ & 7.91 \\
$\mathrm{EC}\left(\mathrm{dS} \mathrm{m}^{-1}\right)$ & 1.03 \\
$\mathrm{WSC}\left(\mathrm{mg} \mathrm{L}^{-1}\right)$ & 103 \\
$\mathrm{TKN}\left(\mathrm{mg} \mathrm{L}^{-1}\right)$ & 3.40 \\
$\mathrm{NO}_{3}^{-}-{\mathrm{N}\left(\mathrm{m} \mathrm{L}^{-1}\right)}_{\mathrm{SO}_{4}{ }^{2-}\left(\mathrm{mg} \mathrm{L}^{-1}\right)}$ & 8.65 \\
$\mathrm{Cl}^{-}\left(\mathrm{mg} \mathrm{L}^{-1}\right)$ & 62.9 \\
$\mathrm{~K}^{+}\left(\mathrm{mg} \mathrm{L}^{-1}\right)$ & 111 \\
$\mathrm{Ca}^{2+}\left(\mathrm{mg} \mathrm{L}^{-1}\right)$ & 126 \\
$\mathrm{Na}^{2+}\left(\mathrm{mg} \mathrm{L}^{-1}\right)$ & 9.08 \\
$\mathrm{Mg}^{2+}\left(\mathrm{mg} \mathrm{L}^{-1}\right)$ & 15.8 \\
\hline
\end{tabular}

EC: electrical conductivity; WSC: water-soluble carbon; TKN: total Kjeldahl nitrogen.

Spinach leaves were manually harvested 80 das, when plants achieved a marketable size [17], and weighed to assess the total yield. Immediately after harvest, the leaves were cold-transported to the Pilot Plant of the Institute of Plant Biotechnology (UPCT), where 
they were stored at $2{ }^{\circ} \mathrm{C}$ and $90 \%$ relative humidity (RH) until the next day when they were processed.

\subsection{Processing, Packaging, and Storage and Atmosphere Analysis}

The plant material was minimally processed in a disinfected cold room at $8{ }^{\circ} \mathrm{C}$. Leaves free of damage and yellowing were selected and immersed first for $1 \mathrm{~min}$ in a solution of chlorinated water $\left(150 \mathrm{ppm} \mathrm{NaOCl}, 4^{\circ} \mathrm{C}\right)$ and then another $1 \mathrm{~min}$ in tap water $\left(4^{\circ} \mathrm{C}\right)$, for disinfection and to remove traces of soil and organic matter. After being drained for $10 \mathrm{~min}$ in a perforated basket, samples of about $150 \mathrm{~g}$ of spinach per treatment were arranged for passive modified atmosphere packaging (MAP) in OPP $35 \mu \mathrm{m}$ plastic bags $(30 \mathrm{~cm} \times 20 \mathrm{~cm}$, Plásticos del Segura, Murcia) thermally sealed simulating a flow pack. The $\mathrm{O}_{2}$ and $\mathrm{CO}_{2}$ transmission rates at $23{ }^{\circ} \mathrm{C}$ and $0 \% \mathrm{RH}$ were similar with $11,000 \mathrm{~cm}^{3} \mathrm{~m}^{-2} \mathrm{~d}^{-1} \mathrm{~atm}^{-1}$ (data provided by the supplier). Three replicates for each fertilization treatment and MAP storage duration (processing day and after 6 and 12 days) were prepared and stored in darkness at $4{ }^{\circ} \mathrm{C}$. Each sampling day, and before opening the bags, atmosphere composition within packages was assessed by an $\mathrm{O}_{2} / \mathrm{CO}_{2}$ headspace analyser (PBI-Dansensor CheckPoint, Ringsted, Denmark).

\subsection{Nitrate, Nitrite, and Oxalate Content}

The ion content was determined following the method described by Lara et al. [22]. Ions were extracted in triplicate per treatment. The extraction of $0.2 \mathrm{~g}$ of dry leaf samples of each treatment was carried out with $50 \mathrm{~mL}$ distilled water and agitation in an orbital shaker (Stuart SSL1, Stone, UK) for $45 \mathrm{~min}$ at $110 \mathrm{rpm}$ at $50^{\circ} \mathrm{C}$. Ion concentration was determined by ion chromatography (850 Professional IC, Metrohm AG, Zofingen, Switzerland) using a Metrosep A SUPP 5 column (Metrohm AG, Zofingen, Switzerland) at a flow rate of $0.7 \mathrm{~mL} \mathrm{~min}^{-1}$ for the anion.

\subsection{Total Phenolic Content}

For tissue preparation, the spinach leaves were frozen in liquid $\mathrm{N}_{2}$, ground with a mincer (IKA A 11 basic, Berlin, Germany) and stored at $-80^{\circ} \mathrm{C}$. Ground frozen leaves $(1 \mathrm{~g})$ were homogenized for $1 \mathrm{~min}$ by Ultra-Turrax (T-25, Ika-Labortechnik, Staufen, Germany) with $3 \mathrm{~mL}$ of a mixture of $\mathrm{MeOH} /$ water $(8 / 2, v / v)$ containing $4 \mathrm{mM} \mathrm{NaF}$. The extraction was carried out in an orbital shaker (Stuart, Staffordshire, UK) for $1 \mathrm{~h}$ at $200 \times g$ in darkness inside a polystyrene box with an ice bed. Afterward, $2 \mathrm{~mL}$ of extracts were transferred in two $2 \mathrm{~mL}$ Eppendorf tubes and centrifuged at $12,500 \times \mathrm{g}$ for $10 \mathrm{~min}$ at $4{ }^{\circ} \mathrm{C}$. The supernatant was used as a total phenolics and total antioxidant capacity extract for each sample. The amount of total phenolic content (TPC) was determined by the Folin-Ciocalteu colorimetric method, according to Singleton et al. [23], with some modifications described by MartinezHernández et al. [24]. A $19.2 \mu \mathrm{L}$ aliquot of extract and $29 \mu \mathrm{L}$ of $1 \mathrm{~N}$ Folin-Ciocalteau were mixed in a well plate and incubated for $3 \mathrm{~min}$ in darkness at room temperature. Then, $192 \mu \mathrm{L}$ of a solution containing $\mathrm{Na}_{2} \mathrm{CO}_{3}(0.4 \%)$ and $\mathrm{NaOH}(2 \%)$ were added. After $1 \mathrm{~h}$ of incubation, at room temperature in darkness, the absorbance was measured at $750 \mathrm{~nm}$ using a multiscan plate reader (Tecan Infinite M200, Männderof, Switzerland). Total phenolic

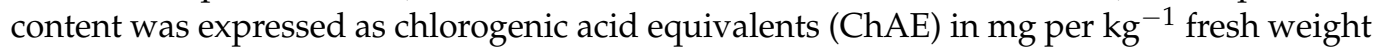
(FW). All extracts were analysed in triplicate.

\subsection{Total Antioxidant Capacity}

The same sample extract to determine TPC was used to evaluate the total antioxidant capacity (TAC) by ferric reducing antioxidant power (FRAP) [25]. Briefly for FRAP, a daily reaction solution containing sodium acetate buffer ( $\mathrm{pH}$ 3.6), $10 \mathrm{mM}$ TPTZ solution (in $40 \mathrm{mM} \mathrm{HCl}$ ), and $20 \mathrm{mM} \mathrm{FeCl}_{3}$ was prepared in a v:v:v proportion of 10:1:1 and incubated at $37^{\circ} \mathrm{C}$ for $2 \mathrm{~h}$ in darkness. Then, $6 \mu \mathrm{L}$ of TAC extract was allowed to react with $198 \mu \mathrm{L}$ of the FRAP solution for $40 \mathrm{~min}$ at room temperature in darkness. The TAC by FRAP was measured by the decrease in absorbance at $593 \mathrm{~nm}$ of the multiscan plate reader. The 
results were expressed as $\mathrm{mg}$ of Trolox equivalents antioxidant capacity $\mathrm{kg}^{-1} \mathrm{FW}$ of three replicates per each treatment.

\subsection{Color}

Color was determined using a colorimeter (Minolta CR-400 Series, Ramsey, NJ, USA). Measurements were recorded using the standard tristimulus parameters $\left(\mathrm{L}^{*}, \mathrm{a}^{*}, \mathrm{~b}^{*}\right)$ of the CIE Lab system on three equidistant points of each replicate. Total color differences $\left(\Delta \mathrm{E}^{*}\right)$ throughout storage compared to their respective initial values were calculated according to the equation $\Delta \mathrm{E}^{*}=\left[\left(\mathrm{L}_{0}^{*}-\mathrm{L}^{*}\right)^{2}+\left(\mathrm{a}_{0}^{*}-\mathrm{a}^{*}\right)^{2}+\left(\mathrm{b}_{0}^{*}-\mathrm{b}^{*}\right)^{2}\right]^{1 / 2}[26]$.

\subsection{Microbial Analyses}

To determine mesophilic and psychrophilic aerobic bacteria, enterobacteria, and yeast and mould growth, standard enumeration methods were used. Samples of $1 \mathrm{~g}$ were homogenized in $10 \mathrm{~mL}$ of sterile peptone saline solution ( $\mathrm{pH}$ 7; Scharlau Chemie SA, Barcelona, Spain) for $10 \mathrm{~s}$ in a sterile stomacher bag (model 400 Bags 6141, London, UK) using a masticator (Colwort Stomacher $400 \mathrm{Lab}$, Seward Medical, London, UK). For the enumeration of each microbial group, 10-fold dilution series were prepared in $9 \mathrm{~mL}$ of sterile peptone saline solution. Mesophilic, enterobacteria, and psychrotrophic were pour plated, and yeast and mould were spread plated. The following media and incubation conditions were used: plate count modified agar (PCA) (Scharlau Chemie, Barcelona, Spain) for mesophilic and psychrotrophic aerobic bacteria, incubated at $30^{\circ} \mathrm{C}$ for $48 \mathrm{~h}$ and at $5^{\circ} \mathrm{C}$ for 7 days, respectively; violet red bile dextrose agar (Scharlau Chemie, Barcelona, Spain) for enterobacteria, incubated at $37^{\circ} \mathrm{C}$ for $48 \mathrm{~h}$; and rose Bengal agar (Scharlau Chemie, Barcelona, Spain) for yeasts and moulds, incubated for $3-5$ days at $22^{\circ} \mathrm{C}$. All microbial counts were reported as log colony forming units per gram of product $\left(\log \mathrm{CFU} \mathrm{g}{ }^{-1}\right)$. Each of the three replicates was analyzed by duplicate. The presence of Listeria monocytogenes was monitored according to the European legislation (Regulation EC 1441/2007, 2007).

\subsection{Sensory Evaluation}

Sensory analyses were performed according to international standards (ASTM STP 9133, ASTM, 1986). The evaluation of spinach samples was performed by a trained sensory panel of 5 people (aged 30-50). Still mineral water was used as a palate cleanser. A 9-point hedonic scale was scored for visual symptoms of browning and dehydration $(9=$ none; $5=$ limit of usability, $1=$ extreme) and other parameters, such as visual appearance, flavor, aroma, texture, color and overall quality, were scored as $1=$ extremely bad; $5=\operatorname{limit}$ of usability; $9=$ excellent.

\subsection{Statistical Analysis}

Analysis of variance (one-way ANOVA) was performed for yield, in which fertilizer treatments (Control, Control + CE, NPK, NPK + CE, DMPP and DMPP + CE) were included. When significant differences were observed, the LSD test was applied. In addition, when the variables were measured during storage, a two-way ANOVA was performed in which the above-mentioned fertilizer treatments and storage time $(0,6$, and $12 \mathrm{~d})$ were included. When interactions were significant they were included in the ANOVA, a LSD test was performed to compare fertilizer treatments and storage time. All the statistical analysis was performed with Statgraphics Plus X for Windows, version 2.1.

\section{Results}

The yields of spinach obtained in both control and Control + CE treatments were significantly lower than in the other treatments, which did not exhibit any significant differences among them (Table 2). In addition, the Control + CE treatment significantly reduced spinach yield in comparison to the control (3.5 vs. $\left.3.9 \mathrm{~kg} \mathrm{~m}^{-2}\right)$. 
Table 2. Influence of different fertilizer treatments on spinach yield. Different letters indicate significant differences at $p<0.05$.

\begin{tabular}{cc}
\hline Treatments & Yield $\mathbf{( k g ~ m}^{-\mathbf{2}} \mathbf{~}$ \\
\hline Control & $3.95 \pm 0.06 \mathrm{~b}$ \\
Control + CE & $3.47 \pm 0.33 \mathrm{a}$ \\
NPK & $4.49 \pm 0.13 \mathrm{c}$ \\
NPK + CE & $4.37 \pm 0.92 \mathrm{c}$ \\
DMPP & $4.59 \pm 0.28 \mathrm{c}$ \\
DMPP + CE & $4.40 \pm 0.11 \mathrm{c}$ \\
\hline
\end{tabular}

Table 3 presents the effects of fertilization treatments, storage time and their interaction on the ion contents, total phenolic content (TPC), total antioxidant capacity (TAC), and microbial load in spinach leaves. Statistical analysis showed a significant interaction between both factors for nitrate, nitrite, TPC, mesophilic and psychrophilic aerobic bacteria and yeast and moulds, whereas no significant interaction was observed for oxalate, antioxidant capacity, and enterobacteria.

Table 3. Influence of fertilization and storage on the ion contents (nitrate, nitrite, oxalate), total phenolic content (TPC), total antioxidant capacity (TAC), and microbial load (mesophilic and psychrophilic aerobic bacteria, enterobacteria and yeast and moulds) in spinach leaves at harvest.

\begin{tabular}{|c|c|c|c|}
\hline \multirow[t]{2}{*}{ Parameters } & \multicolumn{3}{|c|}{ Significant Differences } \\
\hline & Treatments & Storage & Interaction \\
\hline Nitrate $\left(\mathrm{mg} \mathrm{kg}^{-1} \mathrm{FW}\right)$ & $* * *$ & n.s. & ** \\
\hline Nitrite $\left(\mathrm{mg} \mathrm{kg}^{-1} \mathrm{FW}\right)$ & $* * *$ & $* * *$ & $* * *$ \\
\hline Oxalate $\left(\mathrm{mg} \mathrm{kg}^{-1} \mathrm{FW}\right)$ & $* *$ & $* * *$ & n.s. \\
\hline TPC (mg ChAE kg $\left.{ }^{-1} \mathrm{FW}\right)$ & $* * *$ & $* * *$ & $* * *$ \\
\hline TAC $\left(\mathrm{mg}\right.$ Trolox $\left.\mathrm{kg}^{-1} \mathrm{FW}\right)$ & $* *$ & $* * *$ & n.s. \\
\hline Mesophilic aerobic bacteria $\left(\log \mathrm{CFU} \mathrm{g}^{-1}\right)$ & $* * *$ & $* * *$ & $* *$ \\
\hline Psychrophilic aerobic bacteria $\left(\log \mathrm{CFU} \mathrm{g}^{-1}\right)$ & $* * *$ & $* * *$ & $* * *$ \\
\hline Enterobacteria $\left(\log \mathrm{CFU} \mathrm{g}{ }^{-1}\right)$ & $* * *$ & $* * *$ & n.s. \\
\hline Yeast and moulds (log CFU g $\left.{ }^{-1}\right)$ & * & $* * *$ & $* *$ \\
\hline
\end{tabular}

At harvesting, the nitrate content ranged from $215 \mathrm{mg} \mathrm{kg}^{-1} \mathrm{FW}$ for Control + CE to around $333 \mathrm{mg} \mathrm{kg}^{-1} \mathrm{FW}$ for NPK and DMPP (Figure 1a). Nitrate content in the control treatment was reduced by the addition of $\mathrm{CE}$, although in the rest of the treatments, $\mathrm{CE}$ addition did not have any effect. After 6 days of storage, there were no differences in the nitrate contents among the fertilizer treatments, except for those with the nitrification inhibitor, whose values increased significantly $(10 \%$ and $20 \%$ for DMPP and DMPP + CE, respectively, in relation to those obtained at harvest). Furthermore, there were hardly differences among nitrate content values at 6 and 12 days of storage for all the treatments.

Regarding the nitrite content, the lowest value at harvesting was also obtained for the treatment Control $+\mathrm{CE}\left(16 \mathrm{mg} \mathrm{kg}^{-1} \mathrm{FW}\right)$, while the highest value was found in the plants grown in the treatment with NPK (34 mg kg${ }^{-1} \mathrm{FW}$ ) (Figure 1b). In general, the nitrite concentration increased during shelf-life, reaching the highest value $\left(52 \mathrm{mg} \mathrm{kg}^{-1} \mathrm{FW}\right)$ for the treatment NPK at 12 days of storage.

There were no significant differences among the fertilization treatments at harvest. Regarding storage, the general trend was a slight decrease with respect to the initial content for all treatments, this decrease was more severe at the end of storage (Figure 1c), with significant differences found in the Control, Control $+\mathrm{C}$, NPK $+\mathrm{C}$, and DMPP + CE treatments with respect to their initial values. 

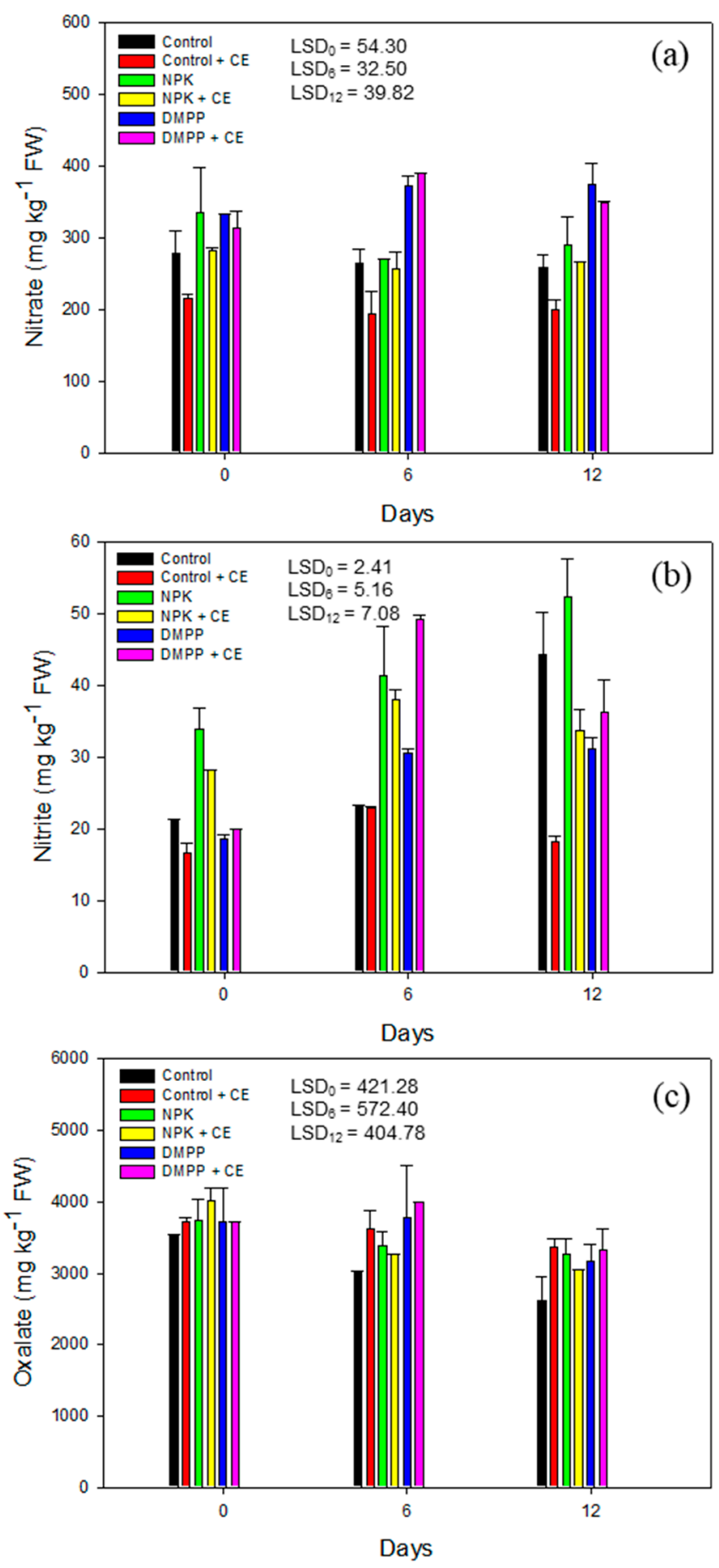

Figure 1. The nitrate (a), nitrite (b), and oxalate (c) content of fresh spinach leaves at 0,6 , and 12 days of storage at $4{ }^{\circ} \mathrm{C}$. Control; Control $+\mathrm{CE}$, control with compost extract; NPK, inorganic NPK fertilizer 15-15-15; NPK + CE, inorganic NPK with compost extract; DMPP, ENTEC Nitrofoska ${ }^{\circledR}$ plus the nitrification inhibitor (IN) 3,4-dimethylpyrazole phosphate (DMPP); DMPP + CE, the nitrification inhibitor (IN) with compost extract.

The initial TPC of spinach leaves ranged from $1253.3 \pm 6.5$ to $1452.4 \pm 51.7 \mathrm{mg}$ ChAE $\mathrm{kg}^{-1} \mathrm{FW}$, observing the lowest values for the control treatment and the highest for the Control $+\mathrm{CE}$ treatment, respectively (Figure 2). A general decreasing trend (between $13-30 \%$ ) was observed after 6 days of storage for all the treatments. However, at the end of storage, TPC values increased markedly for all the treatments, particularly for Control $+\mathrm{CE}$ 
and DMPP + CE. Independently of these changes, the TPC values at the end of spinach shelf life were very similar to those observed at harvest.

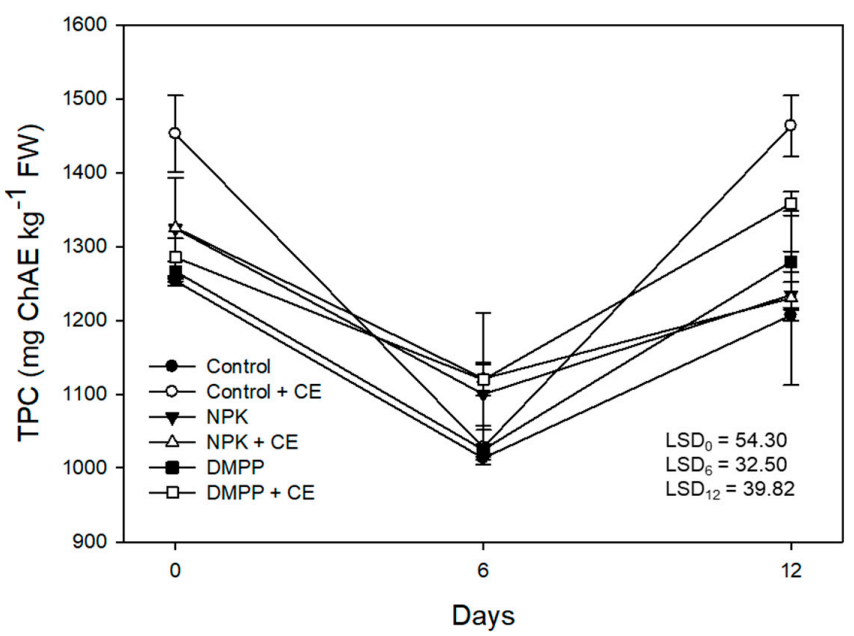

Figure 2. Total phenolic content of fresh spinach leaves at 0,6 , and 12 days of storage at $4{ }^{\circ} \mathrm{C}$. Control; Control + CE, control with compost extract; NPK, inorganic NPK fertilizer 15-15-15; NPK + CE, inorganic NPK with compost extract; DMPP, ENTEC Nitrofoska ${ }^{\circledR}$ plus the nitrification inhibitor (IN) 3,4-dimethylpyrazole phosphate (DMPP); DMPP + CE, the nitrification inhibitor (IN) with compost extract.

The total antioxidant capacity (TAC) at harvesting ranged from $1226.5 \pm 88.1$ to $1453.8 \pm 38.9 \mathrm{mg}$ TROLOX kg ${ }^{-1} \mathrm{FW}$ for Control $+\mathrm{CE}$ and control respectively, with significant differences between them (Figure 3). After 6 days of storage, the TAC values decreased, with a strong decrease for control and Control + CE (17\%). At the end of the storage, the TAC values remained stable for all treatments, with significantly higher values for Control + CE, DMPP, and DMPP + CE. Regarding storage, the general trend was a decrease with respect to the initial content for all treatments.

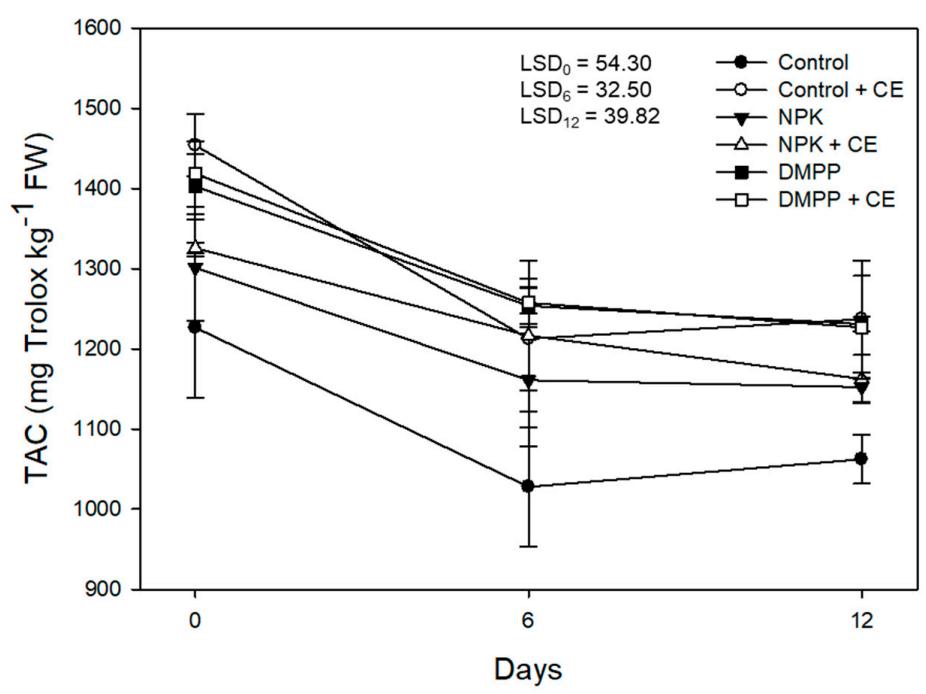

Figure 3. Total antioxidant capacity measured by ferric reducing antioxidant power (FRAP) of fresh spinach leaves at 0,6 , and 12 days of storage at $4{ }^{\circ} \mathrm{C}$. Control; Control $+\mathrm{CE}$, control with compost extract; NPK, inorganic NPK fertilizer 15-15-15; NPK + CE, inorganic NPK with compost extract; DMPP, ENTEC Nitrofoska ${ }^{\circledR}$ plus the nitrification inhibitor (IN) 3,4-dimethylpyrazole phosphate (DMPP); DMPP + CE, the nitrification inhibitor (IN) with compost extract. 
Spinach leaves showed a progressive change in color, this effect increasing during storage for several fertilization treatments. At the end of shelf-life, the highest differences in color as regards to the initial values were detected for DMPP and DMPP + CE (Figure 4). That color change was related to higher values of $a^{*}$ and $b^{*}$ for that treatment compared to the others (data not shown) indicating a slight trend towards yellowing. Independently of that, the highest $\Delta \mathrm{E}^{*}$ values for all the treatments were always below 2 .

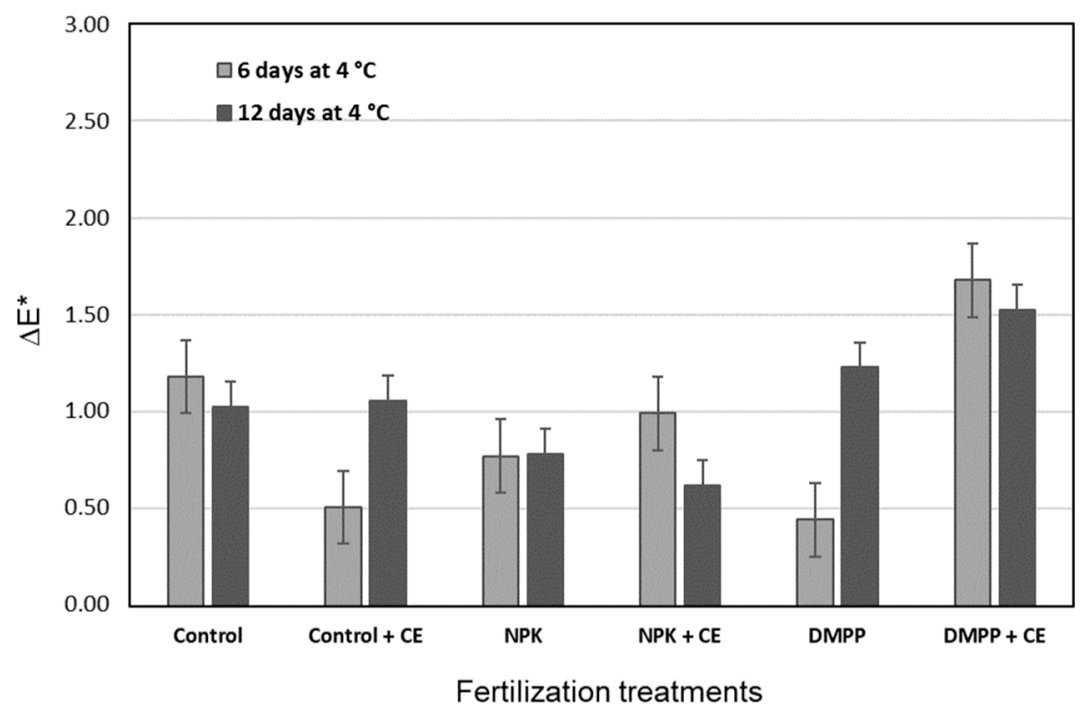

Figure 4. Total color differences $\left(\Delta \mathrm{E}^{*}\right)$ of fresh spinach leaves with different fertilizer treatment after 6 and 12 days of storage at $4{ }^{\circ} \mathrm{C}$. Control; Control $+\mathrm{CE}$, control with compost extract; NPK, inorganic NPK fertilizer 15-15-15; NPK + CE, inorganic NPK with compost extract; DMPP, ENTEC Nitrofoska ${ }^{\circledR}$ plus the nitrification inhibitor (IN) 3,4-dimethylpyrazole phosphate (DMPP); DMPP + CE, the nitrification inhibitor (IN) with compost extract.

The initial microbial load of mesophilic bacteria ranged from $3.95 \pm 0.04$ to $5.16 \pm$ $0.32 \log$ CFU g ${ }^{-1}$ for DMPP and NPK respectively, with significant differences between them (Figure 5). As expected, at the end of storage, microbial loads increased for all the treatments, until reaching $5.84 \pm 0.25 \log \mathrm{CFU} \mathrm{g}^{-1}$ in the NPK + CE treatment.

As for mesophilic bacteria, the initial psychrophilic bacteria load of spinach leaves was significantly higher for treatment NPK $\left(5.79 \pm 0.12 \log C F U ~ g^{-1}\right)$ as related to the other treatments. However, there was a significant increase in the psychrophilic bacteria for all fertilization treatments at the end of the storage, without differences between them and with values between 6.29 and $6.71 \log \mathrm{CFU} \mathrm{g}{ }^{-1}$.

As was expected, the initial counts of enterobacteria were lower than those for mesophilic and psychrophilic bacteria, ranging from 3.44 to $4.55 \log \mathrm{CFU} \mathrm{g}^{-1}$. Similarly that for the other microbial groups, enterobacteria counts significantly increased for all the treatments after 6 days of storage. At the end of shelf life, little changes were observed.

Finally, the initial yeast and moulds counts ranged from 3.19 to $3.83 \log \mathrm{CFU} \mathrm{g}{ }^{-1}$. At the end of storage, these counts significantly increased on average around $1.18 \log \mathrm{CFU} \mathrm{g}^{-1}$ for all the treatments and without differences between them. 


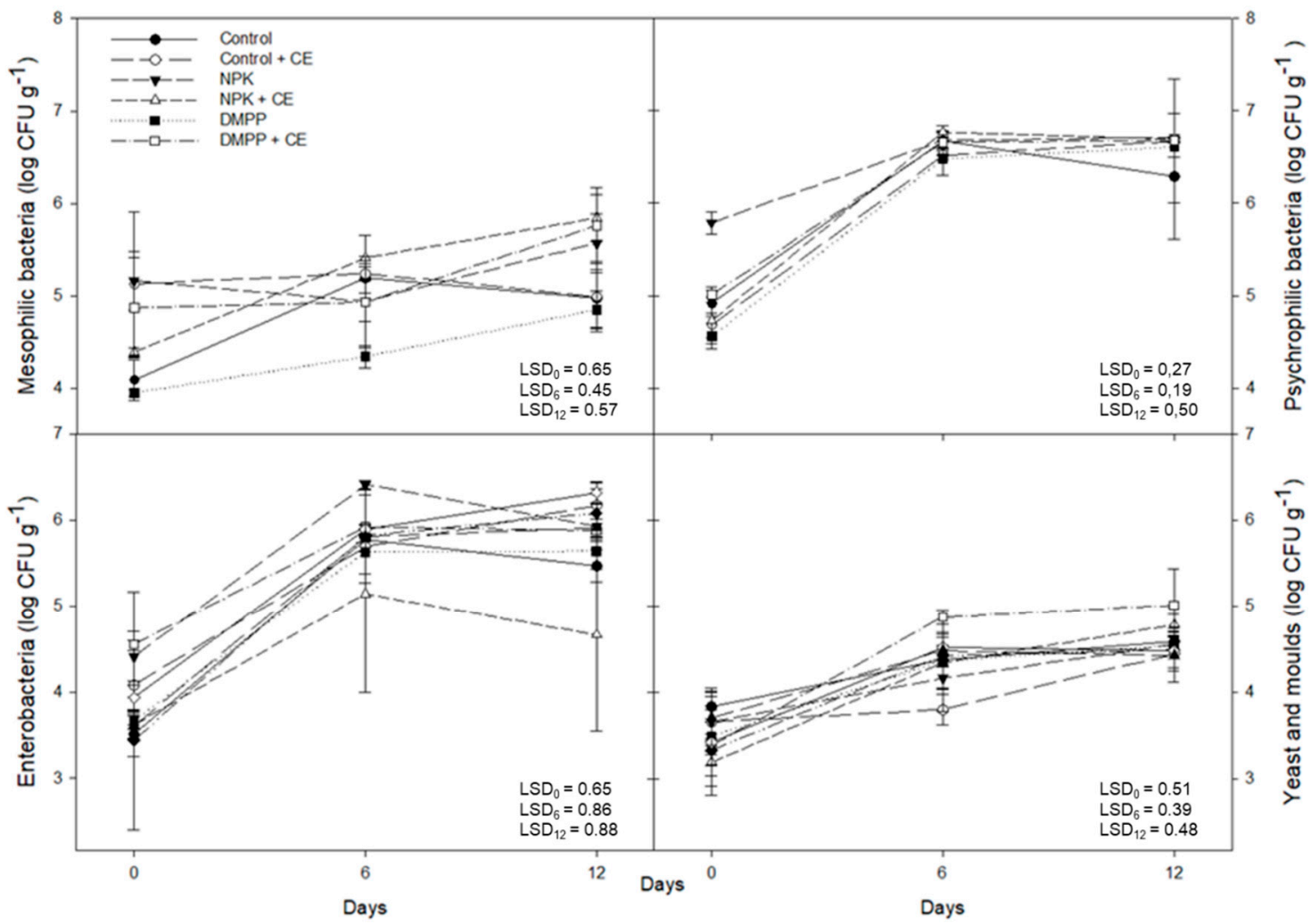

Figure 5. Mesophilic bacteria, psychrophilic bacteria, enterobacteria and yeast and moulds counts $\left(\log \mathrm{CFU} \mathrm{g}^{-1}\right)$ of fresh spinach leaves grown after different fertilizer treatment and storage at $4{ }^{\circ} \mathrm{C}$ for up to 12 days. Control; Control $+\mathrm{CE}$, control with compost extract; NPK, inorganic NPK fertilizer 15-15-15; NPK + CE, inorganic NPK with compost extract; DMPP, ENTEC Nitrofoska ${ }^{\circledR}$ plus the nitrification inhibitor (IN) 3,4-dimethylpyrazole phosphate (DMPP); DMPP + CE, the nitrification inhibitor (IN) with compost extract.

The effects of the different treatments on the sensory quality of spinach leaves are shown in Figure 6. Initial values were optimal and similar for all the treatments, averaging them as reference for comparison with those obtained during storage (Figure 6). The mean scores for all sensory attributes at day 6 indicated greater dehydration for DMPP, as well as for Control + CE than for the other fertilization treatments. In the rest of the sensory parameters, any difference was observed among the treatments. On day 12 , the spinach leaves were seen as visually more dehydrated than on day 6 for all the fertilization treatments, especially for DMPP, control and Control + CE. On the other side, almost no change in flavour and aroma were detected. The atmosphere reached at the end of the cold storage was already the same for all the cases, independently of the treatment and with $\mathrm{CO}_{2}$ and $\mathrm{O}_{2}$ concentrations around $10 \mathrm{kPa}$ for each one of them (data not shown). Yellowness was not detected by the trained panel. Only a slight loss of green colour intensity was observed, but without differences among the treatments. Additionally, the loss in texture seemed to follow the same trend as the dehydration, with the control and Control $+\mathrm{CE}$ treatments showing a poorer texture than the rest. 


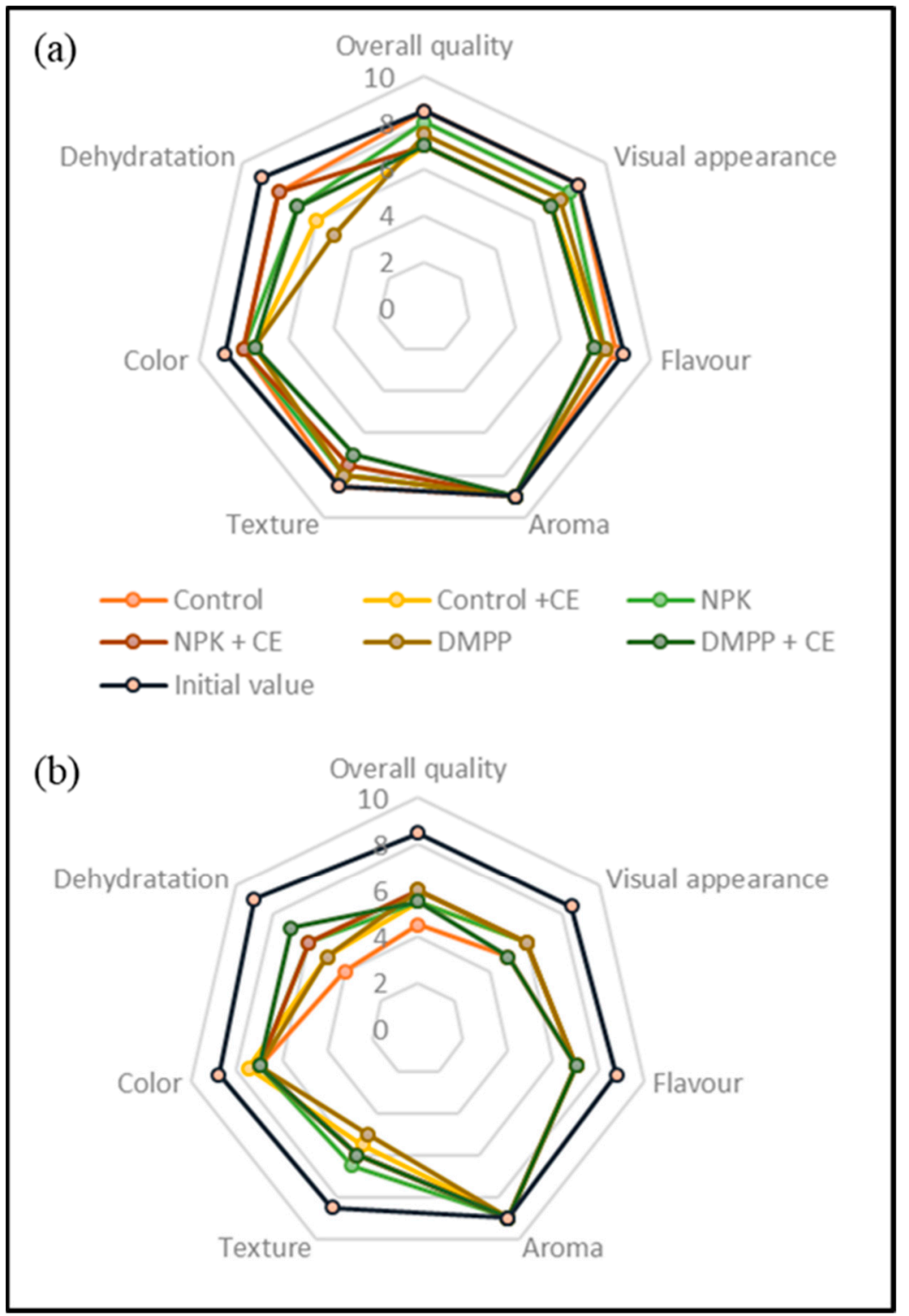

Figure 6. Sensory quality of spinach leaves after (a) 6 and (b) 12 days of storage at $4{ }^{\circ} \mathrm{C}$. Control; Control + CE, control with compost extract; NPK, inorganic NPK fertilizer 15-15-15; NPK + CE, inorganic NPK with compost extract; DMPP, ENTEC Nitrofoska ${ }^{\circledR}$ plus the nitrification inhibitor (IN) 3,4-dimethylpyrazole phosphate (DMPP); DMPP + CE, the nitrification inhibitor (IN) with compost extract.

\section{Discussion}

The addition of $\mathrm{CE}$ to the fertilizers tested did not affect adversely the yield, except for control plants where a decrease was observed. The latter result is in agreement with that obtained by Gimenez et al. [20], who applied a CE by micro-sprinkler in baby leaf lettuce grown hydroponically and obtained a lower yield than the control. Other authors [27] have reported that the application of two microbial compost teas did not result in improved crop yields in spinach. Nevertheless, Ros et al. [19] demonstrated that the foliar application of a compost tea made from onion and vineyard composts produced a higher spinach yield than the control treatment. This different effect of the application of CE on yield can be attributed to a combination of factors. On the one hand, the concentration of some harmful elements in the $\mathrm{CE}$ (i.e., $\mathrm{Na}^{+}$and $\mathrm{Cl}^{-}$) might produce a negative influence on plant growth On the other hand, the beneficial plant microorganisms that can be found in compost 
teas can have a biostimulant, biofertilizer or biopesticide effect and/or produce growth promoters like phytohormones that can promote a beneficial effect on yield. Therefore, the variations in compost tea quality will probably determine the nature and extent of plant effects [28]. In addition, statistical differences were not observed between the NPK and DMPP in agreement with the results of Vico et al. [17], with or without CE application. Furthermore, results from Sheikhi et al. [29] showed that the application of DMPP had no significant effect on the yield of spinach plant at low and medium levels of $\mathrm{N}$ (50 and $75 \mathrm{mg} \mathrm{N} \mathrm{kg}^{-1}$ soil), but decreased the yield of this plant at the higher level of $\mathrm{N}$ (100 $\mathrm{mg} \mathrm{N} \mathrm{kg}^{-1}$ soil). At harvesting, only in the control treatment, nitrate content was reduced by the addition of $\mathrm{CE}$, while the application of $\mathrm{CE}$ did not affect the nitrate content in the other fertilization treatments. Recently, Ros et al. [19] demonstrated in spinach that the foliar application of compost tea produced plants with lower nitrate content than the control treatment. This could be due to the potential organic mineralization rate from the incorporated $\mathrm{CE}$, which would produce nitrates and thus, reducing nitrification processes provoked by the inhibition of nitrifying bacteria. In addition, the biostimulant effect of the $C E$ could induce changes in the expression of nitrate transporter genes, as well as in several metabolic pathways involved in $\mathrm{N}$ metabolism, leading to a different degree of assimilation of nitrates into amino acids among treatments. Furthermore, the application of DMPP fertilizers increased the nitrate content in the leaf with respect to Control $+\mathrm{CE}$ treatment, in spite of DMPP strongly affecting the nitrification process [18]. In addition, the use of DMPP did not reduce the nitrate concentration in leaves compared with NPK, in agreement with the results of Vico et al. [17]. Furthermore, Canali et al. [30] did not find significant differences for nitrate content when a controlled-release fertilizer composed of urea combined with DMPP was applied in relation to different fertilizers' typologies. However, Irigoyen et al. [31] found that fertilizers containing DMPP greatly reduced nitrate accumulation in a spinach crop. It is well known that the DMPP effectivity depends on several agronomic factors $[32,33]$, which could affect its activity on Nitrosomonas bacteria in the soil that delay ammonium oxidation.

In general, nitrate contents slightly decreased after 6 days of storage for all the treatments (except DMPP treatments) according to the results obtained by Gomez et al. [34] in celery, Miceli et al. [35] in rocket leaves, and Giménez et al. [20] in lettuce. This is because postharvest nitrate reduction requires exogenous microbial nitrate reductase activity, which is unlikely to be achieved without visible loss of quality [36]. However, the dehydration observed during storage could produce a slight increase in the nitrate content observed for DMPP and DMPP + CE on day 6, particularly in the DMPP treatment. Independently of the changes observed for nitrate concentrations, concentrations measured here were low and acceptable for consumption, quite far from the maximum level allowed (3500 $\mathrm{mg} \mathrm{NO}_{3} \mathrm{~kg}^{-1}$ ) by the EU for fresh spinach.

The nitrite content in the spinach leaves ranged between 16 to $52 \mathrm{mg} \mathrm{kg}^{-1} \mathrm{FW}$, values that are similar to those found by Kyriacou et al. [36] in a market survey for winter season spinach. Furthermore, they stated that nitrite can be present at very low levels in leafy vegetables and this fact is not necessarily associated with high nitrate concentrations. Additionally, Mu et al. [37] demonstrated that nitrite concentrations remained undetected $\left(1 \mathrm{mg} \mathrm{kg}^{-1}\right)$ in spinach under low-temperature storage, in agreement with previous studies [38], probably due to the fact that nitrate reductase in leaves of green leafy vegetables tends to be inactivated under cold storage.

Regarding oxalate content, there were no significant differences at harvesting between the fertilizer treatments, except for the control. The values found, which ranged between 3524 and $4024 \mathrm{mg} \mathrm{kg}^{-1} \mathrm{FW}$, can be considered low according to Wang et al. [39]. The nitrogen nutrient is one of the most important agronomic factors for effectively regulating the oxalate levels in plants, particularly the $\mathrm{NH}_{4}{ }^{+}$exposure significantly reduces the oxalate accumulation in the plants by inhibiting the uptake of nitrate [40]. The DMPP treatments were not able to reduce the oxalate content in the leaves, despite inhibiting the nitrification process and prolonging the presence of $\mathrm{NH}_{4}{ }^{+}$in soil [41]. The oxalate 
content decreased in each fertilizer treatment throughout the storage time, in agreement with previous studies carried out in spinach [42] and other five leafy vegetables [43], which could be advantageous for improving the health benefits of spinach.

The content of phenolic compounds found in our experiments was similar to that observed by other researchers [2,19]. The initial TAC in all the compost extract treatments was higher than the content observed for those treatments without, as indicated by Ros et al. [19] in the winter cycle. Then, all the treatments followed the same behaviour with a decrease after 6 days and values close to the initial on day 12. This response could be explained by the specific enzyme activities involved in phenylpropanoid metabolism, including phenylalanine ammonia-lyase (PAL), which catalyses the first committed step in the phenolic biosynthesis pathway, after which individual branch pathways make possible a range of phenylpropanoid secondary compounds as phenols [44]. Moreover, initial processing and packaging might negatively affect the total amount of phenolic compounds, but after this parameter can increase because of a breakdown of supramolecular structures containing phenolic groups. However, according to some reports, this loss of phenolic compounds in green leafy vegetables stored at $4{ }^{\circ} \mathrm{C}$ is limited in comparison to the effect of storing them at higher temperatures [2].

The same decrease observed in TPC after 6 days of storage was also found for the total antioxidant capacity. This positive correlation between phenols and antioxidants has been reported before in leaves and petioles $[45,46]$ with phenols being the major contributors to antioxidant capacity [47]. As detected for phenols, and as it was observed by Ros et al. [19], the highest values for antioxidant capacity were observed for those treatments containing compost extract, particularly for Control + CE and DMPP + CE.

As is reported in previous studies $[48,49]$, the $\Delta E^{*}$ value was the parameter that best described the loss of colour when compared to hue, chroma or $\mathrm{L}^{*} \mathrm{a}^{*} \mathrm{~b}^{*}$ values individually (data not shown). Colour differences found here were lower than in those studies, probably due to a very slight weight loss (ca $0.44 \%$ for all the treatments). Loss of water through transpiration can be attributed to differences in internal relative humidity of the tissue with that of the storage atmosphere. MAP preserved a vapour saturated atmosphere and avoided severe dehydration and the associated yellowing. Different authors [33,50,51] observed a more intensive green colour in leaves due to enhanced chlorophyll content in different species of vegetable crops supplied with fertilizers containing DMPP nitrification inhibitor. In our experiments, DMPP, DMPP $+\mathrm{CE}$, and control had the highest values of $\Delta \mathrm{E}^{*}$. It could be related to the higher dehydration that they had compared to the remaining treatments (Figure 6). Shrink leafy vegetables had a higher chlorophyll degradation and an accelerated greenness loss [52].

According to ISO 12647, only values of total colour differences over 3 are detectable by the human eye. Values found in our study are well below that threshold. Consequently, and in general, the colour changes, even when significant, were not extreme after storage. That is the reason why they were imperceptible to the trained panel, who only detected a slight loss of green colour intensity, but without differences between treatments.

Values for mesophilic bacteria found in this study were similar to those reported in previous experiments for fresh-cut spinach leaves conventionally grown in the same cultivation area [53]. Similarly, as observed in our experiments, psychrophilic bacteria loads around $6 \log$ CFU g ${ }^{-1}$ are usually found for spinach grown on the field [12]. Psychrophilic bacteria are able to grow at cold storage temperatures as those usual for avoiding fresh-cut products deterioration. It is well known that values over $7 \log \mathrm{CFU} \mathrm{g}{ }^{-1}$ for mesophilic and psychrophilic bacteria can be associated with a shorter shelf life [54]. However, in our experiments and independently of the treatments, values above those were not found even at the end of the storage. On the other side, Tudela et al. [55] determined that decreasing $\mathrm{O}_{2}$ concentration from $10 \mathrm{kPa} \mathrm{O}_{2}$ to $1 \mathrm{kPa} \mathrm{O}_{2}$ significantly reduced the development of aerobic psychrophilic bacteria. Consequently, for better control of microbial growth, an optimal atmosphere with $\mathrm{O}_{2}$ around 1-2 $\mathrm{kPa}$ and $\mathrm{CO}_{2}$ close to $10 \mathrm{kPa}$ would be more beneficial in terms of microbial quality. 
On the other side, counts found here for enterobacteria were relatively higher than those observed in the same growing area in previous reports [12] but without differences among treatments. The use of organic fertilizers with dairy manure as the main source is a standard practice in the area of cultivation where our experiments were done, which can increase the risk of Enterobacteriaceae-resistant strains on the soil. The fertilization with non-treated biological soil amendments or pathogen-contaminated irrigation water as well as other practices could increase pathogen load and transmission risks. Among many commodities, spinach and other leafy greens have been associated with multiple E. coli O157:H7 human disease outbreaks [56,57]. Proper disinfection, low oxygen atmospheres (around $1 \mathrm{kPa} \mathrm{O}_{2}$ ), and low temperatures could be used to control spoilage microorganisms on spinach leaves for at least 7 days, so long as the storage does not exceed $5{ }^{\circ} \mathrm{C}$. In our experiments, the adverse effect of low oxygen concentrations on enterobacteria growth was not observed since the lowest values found at the end of storage (day 12) with an atmosphere of $\mathrm{O}_{2}$ was around $10 \mathrm{kPa}$.

After 12 days at $4{ }^{\circ} \mathrm{C}$, all the treatments were above the limit of usability, with the spinach leaves acceptable for consumption. Results found here indicate that the sensory attributes were not affected by the fertilization treatments, being the shelf-life within the usual storage range expected for the industry (10-12 days). The air composition reached within packages was far from any anaerobic atmosphere, which in turns would affect flavour and aroma. Previous reports indicated that the optimal atmosphere to preserve sensory attributes in fresh-cut spinach ranges from 1-2 $\mathrm{kPa} \mathrm{O}$ to 8-10 $\mathrm{kPa} \mathrm{CO}_{2}[58,59]$. In our experiments, $\mathrm{CO}_{2}$ was around $10 \mathrm{kPa}$ for all the treatments. This favours chlorophyll retention, keeping a green colour acceptable for consumers, and preventing the formation of compounds derived from the oxidation of phenols that otherwise would cause browning of cut surfaces.

\section{Conclusions}

The foliar application of compost extract might be convenient for obtaining spinach rich in bioactive compounds and with a low concentration of antinutritional factors. Thus, total phenolics content and total antioxidant capacity are increased for both control and DMPP when CE is added, while the lowest values for nitrate and nitrite content are obtained when $\mathrm{CE}$ is added to the control. In addition, its application has no negative effects on the microbial load of the final product. However, further studies are needed on different fertilizing strategies in order to develop sustainable agricultural production based on the reduced use of fertilizers, maintaining high standards on yield and quality of the product.

Author Contributions: Conceptualization, M.Á.B., M.D.P.-M., M.R. and J.A.P.; methodology, A.G., M.Á.B. and E.M.-S.; validation, A.G., J.A.F. and P.A.G.; data curation, A.G.; writing-original draft preparation, A.G., C.E.-G. and P.A.G.; writing-review and editing, J.A.F., C.E.-G., M.Á.B. and P.A.G.; supervision, J.A.F. and P.A.G. All authors have read and agreed to the published version of the manuscript.

Funding: This research was funded by the Spanish Ministry of Economy and Competitiveness: Reference project: AGL2017-84085-C3-1-R, AGL2017-84085-C3-2-R, AGL2017-84085-C3-3-R.

Institutional Review Board Statement: Not applicable.

Informed Consent Statement: Not applicable.

Conflicts of Interest: The authors declare no conflict of interest.

\section{References}

1. Roberts, J.L.; Moreau, R. Functional properties of spinach (Spinacia oleracea L.) phytochemicals and bioactives. Food Funct. 2016, 7, 3337-3353. [CrossRef] [PubMed]

2. Bunea, A.; Andjelkovic, M.; Socaciu, C.; Bobis, O.; Neacsu, M.; Verhé, R.; Van Camp, J. Total and individual carotenoids and phenolic acids content in fresh, refrigerated and processed spinach (Spinacia oleracea L.). Food Chem. 2008, 108, 649-656. [CrossRef] [PubMed] 
3. Pandjaitan, N.; Howard, L.R.; Morelock, T.; Gil, M.I. Antioxidant capacity and phenolic content of spinach as affected by genetics and maturation. J. Agric. Food Chem. 2005, 53, 8618-8623. [CrossRef] [PubMed]

4. Mou, B. Evaluation of oxalate concentration in the U.S. Spinach Germplasm Collection. HortScience 2008, 43, 1690-1693. [CrossRef]

5. Santamaria, P. Nitrate in vegetables: Toxicity, content, intake and EC regulation. J. Sci. Food Agric. 2006, 86, 10-17. [CrossRef]

6. Noonan, S.C.; Savage, G.P. Oxalic acid and its effects on humans. Asia Pac. J. Clin. Nutr. 1999, 8, 64-74.

7. Tiso, M.; Schechter, A.N. Nitrate Reduction to Nitrite, Nitric Oxide and Ammonia by Gut Bacteria under Physiological Conditions. PLoS ONE 2015, 10, e0119712. [CrossRef]

8. Conversa, G.; Bonasia, A.; Lazziezera, C.; Elia, A. Pre-harvest nitrogen and azoxystrobin application enhances raw produced quality and post-harvest shelf-life of baby spinach (Spinacia oleracea L.). J. Sci. Food Agric. 2014, 94, 3263-3272. [CrossRef]

9. Conte, A.; Conversa, G.; Scrocco, C.; Brescia, I.; Laverse, J.; Elia, A.; Del Nobile, M.A. Influence of growing period on quality of baby spinach leaves at harvest and during storage as minimally processed produce. Postharvest Biol. Technol. 2008, 50, 190-196. [CrossRef]

10. Jung, Y.J.; Padmanabahn, A.; Hong, J.H.; Lim, J.; Kim, H.O. Consumer freshness perception of spinach samples exposed to different storage conditions. Postharvest Biol. Technol. 2012, 73, 115-121. [CrossRef]

11. Francis, F.L. Quality as influenced by color. Food Qual. Prefer. 1995, 6, 149-155. [CrossRef]

12. Rodríguez Hidalgo, S.; Artés-Hernández, F.; Gómez, P.A.; Fernández, J.A.; Artés, F. Quality of fresh-cut baby spinach grown under floating trays system as affected by $\mathrm{N}$ fertilization and innovative package treatments. J. Sci. Food Agric. 2010, 90, 1089-1097. [CrossRef]

13. Medina, M.A.; Tudela, J.A.; Marín, A.; Allende, A.; Gil, M.I. Short postharvest storage under low relative humidity improves quality and shelf life of minimally processed baby spinach (Spinacia oleracea L.). Postharvest Biol. Technol. 2012, 67, 1-9. [CrossRef]

14. Yahia, E.M.; Gardea-Béjar, A.; Ornelas-Paz, J.J.; Maya-Meraz, O.; Rodríguez-Roque, M.J.; Rios-Velasco, C.; Ornelas-Paz, J.; Salas-Marina, M.A. Preharvest factors affecting postharvest quality. In Postharvest Technology of Perishable Horticultural Commodities; Yahia, E.M., Ed.; Elsevier: Cambridge, UK, 2019; pp. 99-128.

15. Zikalala, O.B.; Nkomo, M.; Zikalala, B.O.; Nkomo, M.; Araya, H.; Ngezimana, W.; Mudau1, F.N. Nutritional quality of baby spinach (Spinacia oleracea L.) as affected by nitrogen, phosphorus and potassium fertilisation. S. Afr. J. Plant Soil 2016, 1-8. [CrossRef]

16. Di Mola, I.; Cozzolino, E.; Ottaiano, L.; Nocerino, S.; Rouphael, Y.; Colla, G.; El-Nakhel, C.; Mori, M. Nitrogen Use and Uptake Efficiency and Crop Performance of Baby Spinach (Spinacia oleracea L.) and Lamb's Lettuce (Valerianella locusta L.) Grown under Variable Sub-Optimal N Regimes Combined with Plant-Based Biostimulant Application. Agronomy 2020, 10, 278. [CrossRef]

17. Vico, A.; Sáez, J.A.; Pérez-Murcia, M.D.; Martínez-Tomé, J.; Andreu-Rodriguez, J.; Agulló, E.; Bustamante, M.A.; Sanz-Cobea, A.; Moral, R. Production of spinach in intensive Mediterranean horticultural systems can be sustained by organic-based fertilizer without yield penalties and with low environmental impacts. Agric. Syst. 2020, 178, 102765. [CrossRef]

18. Shi, X.; Hu, H.-W.; Müller, C.; He, J.-Z.; Chen, D.; Suter, H.C. Effects of the nitrification inhibitor 3,4-dimethylpyrazole phosphate on nitrification and nitrifiers in two contrasting agricultural soils. Appl. Environ. Microbiol. 2016, 82, 5236-5248. [CrossRef]

19. Ros, M.; Hurtado-Navarro, M.; Giménez, A.; Fernández, J.A.; Egea-Gilabert, C.; Lozano-Pastor, P.; Pascual, J.A. Spraying Agro-Industrial Compost Tea on Baby Spinach Crops: Evaluation of Yield, Plant Quality and Soil Health in Field Experiments. Agronomy 2020, 10, 440. [CrossRef]

20. Giménez, A.; Fernández, J.A.; Pascual, J.A.; Ros, M.; Egea-Gilabert, C. Application of Directly Brewed Compost Extract Improves Yield and Quality in Baby Leaf Lettuce Grown Hydroponically. Agronomy 2020, 10, 370. [CrossRef]

21. Bustamante, M.A.; Paredes, C.; Moral, R.; Moreno-Caselles, J.; Pérez-Espinosa, A.; Pérez-Murcia, M.D. Uses of winery and distillery effluents in agriculture: Characterisation of nutrient and hazardous components. Water Sci. Technol. 2005, 51, 145-151. [CrossRef]

22. Lara, L.J.; Egea-Gilabert, C.; Niñirola, D.; Conesa, E.; Fernández, J.A. Effect of aeration of the nutrient solution on the growth and quality of purslane (Portulaca oleracea). J. Hortic. Sci. Biotechnol. 2011, 86, 603-610. [CrossRef]

23. Singleton, V.L.; Orthofer, R.; Lamuela-Raventós, R.M. Analysis of total phenols and other oxidation substrates and antioxidants by means of Folin-Ciocalteu reagent. Methods Enzym. 1999, 299, 152-178. [CrossRef]

24. Martinez-Hernández, G.B.; Gómez, P.A.; Pradas, I.; Artés, F.; Artés-Hernández, F. Moderate UV-C pretreatment as a quality enhancement tool in fresh-cut Bimi ${ }^{\circledR}$ broccoli. Postharvest Biol. Technol. 2011, 62, 327-337. [CrossRef]

25. Benzie, L.F.; Strain, J.J. Ferric reducing/antioxidant power assay: Direct measure of total antioxidant activity of biological fluids and modified version for simultaneous measurement of total antioxidant power and ascorbic acid concentration. Methods Enzym. 1999, 299, 15-27. [CrossRef]

26. Walkling-Ribeiro, M.; Noci, F.; Cronin, D.A.; Lyng, J.G.; Morgan, D.J. Shelf life and sensory attributes of a fruit smoothie-type beverage processed with moderate heat and pulsed electric fields. Food Sci. Tecnol. 2010, 43, 1067-1073. [CrossRef]

27. Knewtson, S.J.B.; Griffin, J.J.; Carey, E.F. Application of two microbial teas did not affect collard or Spinach yield. Hortscience 2009, 44, 73-78. [CrossRef]

28. Eudoxie, G.; Martin, M. Compost Tea Quality and Fertility. In Organic Fertilizers-History, Producction and Applications; IntechOpen: London, UK, 2019. [CrossRef]

29. Sheikhi, J.; Hosseini, H.M.; Etesani, H.; Majidi, A. Biochar counteracts nitrification inhibitor DMPP- mediated negative effect on spinach (Spinacia oleracea L.) growth. Ecotoxical Environ. Saf. 2020, 191, 110243. [CrossRef] 
30. Canali, S.; Diacono, M.; Ciaccia, C.; Masetti, O.; Tittarelli, F.; Monterruno, F. Alternative strategies for nitrogen fertilization of overwinter processing spinach (Spinacia oleracea L.) in Southern Italy. Eur. J. Agron. 2014, 54, 47-53. [CrossRef]

31. Irigoyen, I.; Lamsfus, C.; Aparicio-Tejo, P.; Muro, J. The influence of 3,4-dimethylpyrazole phosphate and dicyandiamide on reducing nitrate accumulation in spinach under Mediterranean conditions. J. Agric. Sci. 2006, 144, 555-562. [CrossRef]

32. Barth, G.; Von Tucher, S.; Schmidhalter, U. Influence of soil parameters on the effect of 3,4-dimethylpyrazole-phosphate as a nitrification inhibitor. Biol. Fertil. Soils 2001, 34, 98-102. [CrossRef]

33. Pasda, G.; Hähndel, R.; Zerulla, W. Effect of fertilizers with the new nitrification inhibitor DMPP (3,4-dimethylpyrazole phosphate) on yield and quality of agricultural and horticultural crops. Biol. Fertil Soils 2001, 34, 85-97. [CrossRef]

34. Gómez, P.; Artés, F.; Madrid, R. Nitrogen fertiliser rate and controlled atmospheres effects on the nitrates levels and quality of fresh processed celery sticks. Acta Hortic. 2003, 604, 493-498. [CrossRef]

35. Miceli, A.; Vetraro, F.; Sabatino, L.; D'Anna, F.; Moncada, A. Influence of preharvest Gibberellic acid treatments on postharvest quality of minimally processed leaf lettuce and rocket. Horticulturae 2019, 5, 63. [CrossRef]

36. Kyriacou, M.C.; Soteriou, G.A.; Colla, G.; Rouphael, Y. The occurrence of nitrate and nitrite in Mediterranean fresh salad vegetables and its modulation by pre harvest practices and postharvest conditions. Food Chem. 2019, 285, 468-477. [CrossRef]

37. Mu, Y.; Feng, Y.; Wei, L.; Li, C.; Cai, G.; Zhu, T. Combined effects of ultrasound and aqueous chlorine dioxide treatments on nitrate content during storage and postharvest storage quality of spinach (Spinacia oleracea L.). Food Chem. 2020, 333, 127500. [CrossRef]

38. Chung, J.C.; Chou, S.S.; Hwang, D.F. Changes in nitrate and nitrite content of four vegetables during storage at refrigerated and ambient temperatures. Food Addit. Contam. 2004, 21, 317-322. [CrossRef]

39. Wang, X.; Cai, X.; Xu, C.; Zhao, Q.; Ge, C.; Dai, S.; Wang, Q.-H. Diversity of nitrate, oxalate, vitamin C and carotenoid contents in different spinach accessions and their correlation with various morphological traits. J. Hortic. Sci. Biotechnol. 2018, 93, 409-415. [CrossRef]

40. Cai, X.; Ge, C.; Xu, C.; Wang, X.; Wang, S.; Wang, Q. Expression Analysis of Oxalate Metabolic Pathway Genes Reveals Oxalate Regulation Patterns in Spinach. Molecules 2018, 23, 1286. [CrossRef]

41. Irigoyen, I.; Muro, J.; Azpilikueta, M.; Aparicio-Tejo, P.; Lamsfus, C. Ammonium oxidation kinetics in the presence of nitrification inhibitors DCD and DMPP at various temperatures. Aust. J. Soil Res. 2003, 41, 1177-1183. [CrossRef]

42. Toledo, M.E.A.; Ueda, Y.; Imahori, Y.; Ayaki, M. l-ascorbic acid metabolism in spinach (Spinacia oleracea L.) during postharvest storage in light and dark. Postharvest Biol. Technol. 2003, 28, 47-57. [CrossRef]

43. Acho, F.C.; Zoué, L.T.; Nimké, S.L. Nutritional and antioxidant characterization of blanched leafy vegetables consumed in Southen Côte d'Ivoire (Ivory Coast). Br. Biotechnol. J. 2015, 6, 154-164. [CrossRef]

44. Cisneros-Zevallos, L. The use of controlled postharvest abiotic stresses as a tool for enhancing the nutraceutical content and adding-value of fresh fruits and vegetables. J. Food Sci. 2003, 68, 1560-1565. [CrossRef]

45. Hua-Bin, L.; Chi-Chun, W.; Ka-Wing, C.; Feng, C. Antioxidant properties in vitro and total phenolic contents in methanol extracts from medicinal plants. LWT Food Sci. Technol. 2008, 41, 385-390. [CrossRef]

46. Yosefi, Z.; Tabaraki, R.; Asadi Gharneh, H.; Mehrabi, A. Variation in Antioxidant Activity, Total Phenolics, and Nitrate in Spinach. Int. J. Veg. Sci. 2010, 16, 233-242. [CrossRef]

47. Pascale, A.; Vinale, F.; Manganiello, G.; Nigro, M.; Lanzuise, S.; Ruocco, M.; Marra, R.; Lombardi, N.; Woo, S.L.; Lorito, M. Trichoderma and its secondary metabolites improve yield and quality. Crop. Prot. 2017, 92, 176-181. [CrossRef]

48. Pandrangi, S.; Laborde, L. Retention of folate, carotenoids, and other quality characteristics in commercially packaged fresh spinach. Food Chem. Toxicol. 2004, 69, 702-707. [CrossRef]

49. Gómez-López, V.; Marín, A.; Medina-Martínez, M.; Gil, M.I.; Allende, A. Generation of trihalomethanes with chlorine-based sanitizers and impact on microbial, nutritional and sensory quality of baby spinach. Postharvest Biol. Technol. 2013, 85, 210-217. [CrossRef]

50. Hähndel, R.; Zerulla, W. Effects of Ammonium-stabilized N-Fertilizers on Yield and Quality of Vegetables. Acta Hortic. 2001, 563, 81-86. [CrossRef]

51. Hähndel, R.; Strohm, M. New stabilized N fertilizer: Further studies. Gemüse 2001, 6, 13-16. (In German)

52. Agüero, V.; Ponce, A.; Moreira, M.; Roura, S. Lettuce quality loss under conditions that favor the wilting phenomenon. Postharvest Biol. Technol. 2011, 59, 124-131. [CrossRef]

53. Artés-Hernández, F.; Escalona, V.H.; Robles, P.A.; Martínez-Hernández, G.B.; Artés, F. Effect of UV-C radiation on quality of minimally processed spinach leaves. J. Sci. Food Agric. 2009, 89, 414-421. [CrossRef]

54. Babic, I.; Watada, A. Microbial populations of fresh-cut spinach leaves affected by controlled atmospheres. Postharvest Biol. Technol. 1996, 9, 187-193. [CrossRef]

55. Tudela, J.A.; Marín, A.; Garrido, Y.; Cantwell, M.; Medina-Martínez, M.; Gil, M.I. Off-odour development in modified atmosphere packaged baby spinach is an unresolved problem. Postharvest Biol. Technol. 2013, 75, 75-85. [CrossRef]

56. Ruengvisesh, S.; Kerth, C.; Taylor, T. Inhibition of Escherichia coli O157:H7 and Salmonella enterica isolates on spinach leaf surfaces using eugenol-loaded surfactant micelles. Foods 2018, 8, 575. [CrossRef] [PubMed]

57. Richter, L.; Du Plessis, E.M.; Duvenage, S.; Korsten, L. Occurrence. Identification, and antimicrobial resistance profiles of extended-spectrum and AmpC $\beta$-lactamase-producing Enterobacteriaceae from fresh vegetables retailed in Gauteng Province, South Africa. Foodborne Pathog. Dis. 2019, 16, 421-427. [CrossRef] [PubMed] 
58. Artés, F.; Gómez, P.A.; Aguayo, E.; Artés-Hernández, F. Modified Atmosphere Packaging. In Handbook of Food Safety Engineering; Wiley-Blackwell: Hoboken, NJ, USA, 2012; pp. 543-573.

59. Preetinder, K.; Deepak, R.; Shashi, P. Quality changes in fresh-cut spinach (Spinacia oleracea) under modified atmospheres with perforations. J. Food Qual. 2011, 34, 10-18. [CrossRef] 